\title{
Assessment of Energy Efficient HVAC Systems for Office Buildings
}

\author{
Yunus Emre Ozpolat ${ }^{1 *}$, Yusuf Kara ${ }^{2}$ \\ 1*,2 Department of Mechanical Engineering, Bursa Technical University, 16310, Bursa, Turkey
}

Cite this paper as:

Ozpolat, Y. E. and Kara, Y. (2022).

Assessment of Energy Efficient HVAC

Systems for Office Buildings. Journal of

Innovative Science and

Engineering.6(1):1-21

*Corresponding author: Yunus Emre Ozpolat

E-mail: ozpolatye@gmail.com

Received Date:29/04/2021

Accepted Date:07/07/2021

(C) Copyright2022 by

Bursa Technical University. Available online at http://jise.btu.edu.tr/

\section{cc) (i) (8)}

The works published in Journal of Innovative Science and Engineering (JISE) are licensed under a Creative Commons Attribution-NonCommercial 4.0 International License.

\section{Abstract}

As a result of economic and political requirements, renewable energy investments are supported with various incentives all over the world, while fossil fuel systems are restricted by regulations. This article aims to make conventional heating, cooling and power systems more efficient or to develop an alternative system based on renewable energy by modeling an office building. Considering three scenarios - classical heatingcooling system, combined cooling-heating-power system and zero energy building, the test building's energy estimation analysis and life-cycle cost analysis have been conducted and 3 different sub-scenarios for renewable energy scenarios have been generated. As a result of the Hourly Analysis Program (HAP), the building's cooling design load was found to be $742.7 \mathrm{~kW}$, and the heating design load was $439.8 \mathrm{~kW}$. The required borehole length for ground source heat pump is determined as 20,371 m for cooling and 9,137 m for heating, while the heat is discharged into the borehole with a rate of $-44.3 \mathrm{~W} / \mathrm{m}$ and extracted with a rate of $34 \mathrm{~W} / \mathrm{m}$. Annual energy generation of the photovoltaic plant was determined as $607.639 \mathrm{kWh}$ and installed power of for this plant was calculated as 463 $\mathrm{kWp}$. Lifecycle cost analyses were performed by using P1-P2 method and according to the calculations, the payback period for the extra investment cost is 37 months for the combined cooling-heating-power plant, whereas it is 94 months for the improved zero energy building design. Similarly, the payback period for the full investment cost is determined as 58 months for the combined cooling-heating-power plant, and 127 months for the improved zero energy building design. As a result, a hybrid zero energy building (air source condenser + ground source heat pump, photovoltaic panels) is proposed as the best design option for the office building identity.

Keywords: Life cycle cost analysis, Zero energy building, Combined cooling heating power, Ground source heat pump, Photovoltaic, Hourly analysis program. 


\section{Introduction}

According to the National Energy Efficiency Action Plan issued for 2017-2023 by the Ministry of Energy and Natural Resources of Republic of Turkey, at the national level, the overall share of energy consumption by buildings in the total amount of consumption has reached up to 32.8 percent. Similarly, the same ratio has reached up to 40 percent in the USA and EU [1]. Due to this reason, energy saving applications targeting this sector are on a rapid rise. In the meantime, energy consumptions and system optimizations of buildings are generally examined separately in literature for the building identity (ID) specific applications. These studies generally concentrate on traditional heating-cooling systems, combined cooling, heating and power (CCHP) plants and zero-energy building (ZEB) designs. Although each design has different dynamics of its own, studies undertaken are mostly classified as compliance analyses of chosen buildings according to their building ID and human habitation, energy generation and consumption analyses of systems, cost and payback period analyses and carbon footprint analyses.

Rather than individual examination of building facility scenarios, an optimal system needs to be determined by cross comparing different scenarios suitable to the building ID and energy consumption trends on a global sense. From this point onward, hybrid facilities need to be established by using this optimal system in conjunction with others. In accordance with this insight, Shilei Lu et. al. [2] had coupled CCHP and Ground Source Heat Pump (GSHP) usage. Despite driving the initial investment costs up, they found a $36.2 \%$ decrease in annual operating costs and a 5 years payback period. Md. Shahinur Islam [3] reported that a $43 \%$ decrease in electricity drawn from the grid and a sharp decline of $90 \%$ in emissions were possible without making any changes on the present system other than the integration of photovoltaic (PV) panels over the office building. Minjin Kong et. al. [4] reported that a fully PV based facility with a suggested 25 years operation span consumed 71.3 million kWh energy while generating 420.7 million kWh energy at the same period which translates to a net energy ratio of 5.9. This number dropped to 3.86 if the operation span was adjusted to 15 years. F. Asdrubali et al. [5] performed improvement studies, along with an economic analysis for two different scenarios, concerning carbon footprint. Their first scenario was the nearly-zero energy building (nZEB) design which yielded an economical payback period of 6.9 years, along with a 6.5 years carbon payback period, meanwhile for the second scenario, same metrics were reported as 6.6 years and 5.9 years respectively. The US Department of Energy's 2019 study, titled "International Energy Outlook 2019 with projections to 2050" strongly indicated that the usage of renewable energy as the primary energy source, shown in Figure 1, will overtake coal and natural gas in early 2030s and petroleum-derived products in 2040s. 


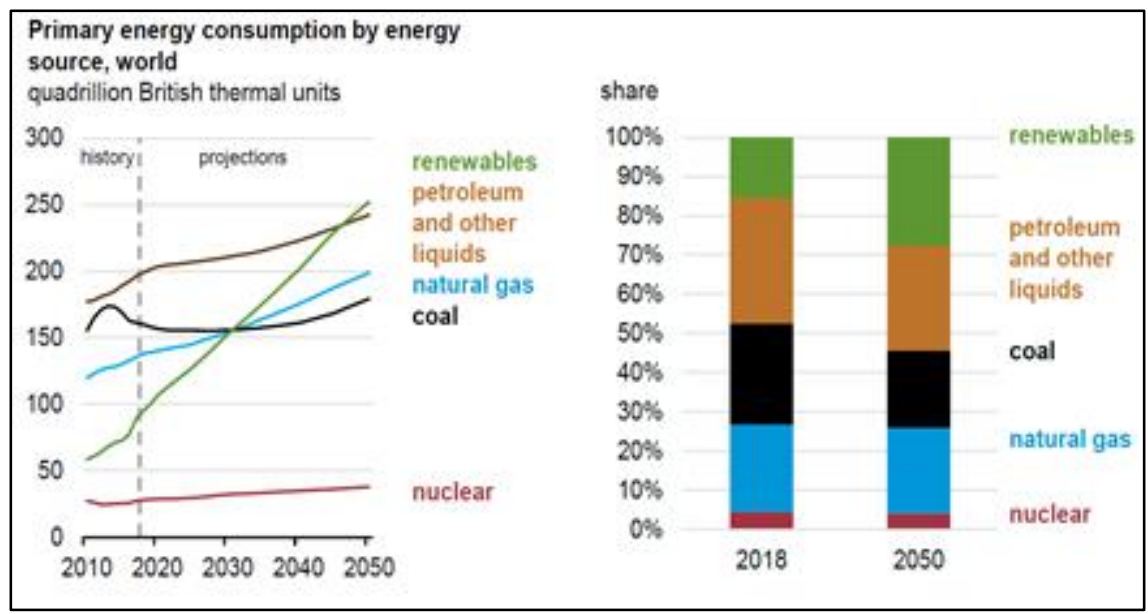

Figure 1. Primary energy consumption by energy source.

The aim of this study is primarily to simulate a case building in a numerical setup by its heating and cooling load and then perform energy analyses appropriate for the office building ID, the conditions of usage and human habitation. By including building energy facility alternatives into the simulation, the most economically advantageous system appropriate for the building is determined with the usage of the Life-Cycle Cost Analysis (LCCA). Due to the requirements forced by current and projected regulations upon the fossil fuel-based systems, in the EU as well as in Turkey, the renewable energy based facility alternatives is improved with the help of hybrid usage, which in turn shortens payback periods considerably.

\section{Material and Methods}

\subsection{Case Building Information}

The case building in our study is the public building of the Ministry of Environment and Urbanization's provincial branch, located in the city of Bursa, which is a 6-storey building with a base area of $1558 \mathrm{~m}^{2}$ and an overall $9026 \mathrm{~m}^{2}$ indoor space. Located in the downtown area of the city, the building is surrounded with a variety of public and private buildings. Essentially as an office building, it also has other sorts of living quarters like meeting and conference halls, a guesthouse section, and a cafeteria. The bulk of human habitation occurs between 08:00 and 17:00 hours during workdays. In all living quarters, 4-piped fan-coils capable of simultaneous heating and cooling are used. All the main pumps of heating and cooling systems are working with a frequency converter. In all the air-conditioned spaces, the temperature control is provided by thermostats and the boilers are working in conjunction with outdoor air sensors. All the fan coils have combined balance valves on both heating and cooling lanes. The case building has the natural ventilation capabilities though it has no forced ventilation. Building insulation is in compliance with the national TS 825 standards, and the thermal transmission coefficients of the outer shell components are presented in Table 1.

Table 1. Case building thermal transmission coefficients of the outer shell structural components $\left(\mathrm{W} / \mathrm{m}^{2} \mathrm{~K}\right)$.

\begin{tabular}{lllll}
\hline $\mathrm{U}_{\text {outerwall }}$ & $\mathrm{U}_{\text {floor }}$ & $\mathrm{U}_{\text {roof }}$ & $\mathrm{U}_{\text {window }}$ & $\mathrm{U}_{\text {exteriordoor }}$ \\
\hline 0.47 & 0.39 & 0.34 & 2.1 & 5.5 \\
\hline
\end{tabular}




\subsection{Calculation and Analysis Methods}

The calculations and analyses constituting the base for the scenarios are presented in detail in section 2.3 , which is performed under four main sections: building heating-cooling load and energy analysis, vertical borehole length calculation for GSHP, PV calculations and LCCA calculations.

\subsubsection{Load and Energy Analysis}

Case building heating-cooling load calculations ( $\dot{\mathrm{Q}}, \dot{\mathrm{Q}} \mathrm{c})$ and annual heating energy, cooling energy and electrical energy analysis (Ec, Eh, Eel) are performed by using Carrier Hourly Analysis Program (HAP). In order to calculate building heat flow, the program is using ASHREA Transfer Function Method generated from the heat balance method. It performs energy analysis on building's heat transfer loads and the operation of the equipment by using the meteorological data for 8,760 hours of the year. The data pertaining to architecture, space and utilization, cost of energy sources (natural gas, electricity), and the quantity and efficiency values of the instruments that constitutes the basis for the analysis are determined manually according to the case building profile by the user, and then the program is executed. In accordance with the calculation results, the pricing of the equipment choice in order to perform economic analysis are done by the user in compliance with the company catalogs.

\subsubsection{Vertical Boreholes Calculation}

The choice of source for the heat pump to be used is an important criterion initial investment, operating costs and energy generation. Due to the sunlight reaching on the surface of the earth, the uppermost layer called epithermal region, which extends between $0-1 \mathrm{~m}$ in depth, is affected by the daily temperature changes meanwhile the subsequent layer ranging from $1 \mathrm{~m}$ up to between $8-20 \mathrm{~m}$ is only affected by the annual temperature changes, and in the case of so called mesothermal region ranging further from between $20-80$ meters to $100 \mathrm{~m}$ is only exposed to $1{ }^{\circ} \mathrm{C}$ temperature change per century and this region in which temperature change does not exceed $0.4{ }^{\circ} \mathrm{C}$ in 30 years is also stated as stable temperature zone by name [6]. Factors such as the aim of less area use originating from the high heating and cooling load, more stable temperature supply in further depths of the earth, the backfill additives enriched with the moist quality of earth and achievement of effective heat transfer by increased surface area are the qualities that brings the vertical borehole forward. Vertical borehole calculation for GSHP is performed in accordance with ASHRAE calculation criteria. In this way, the borehole lengths $\left(\mathrm{L}_{\mathrm{c}}, \mathrm{L}_{\mathrm{h}}\right)$ necessary for cooling and heating are calculated by the equations displayed in Eqs. 1a ve 1b respectively [7].

$$
\begin{aligned}
& \mathrm{L}_{\mathrm{c}}=\frac{\mathrm{q}_{\mathrm{a}} \mathrm{R}_{\mathrm{ga}}+\left(\mathrm{q}_{\mathrm{lc}}-\mathrm{W}_{\mathrm{c}}\right)\left(\mathrm{R}_{\mathrm{b}}+P L F_{\mathrm{m}} \mathrm{R}_{\mathrm{gm}}+\mathrm{R}_{\mathrm{gd}} \mathrm{F}_{\mathrm{sc}}\right)}{\mathrm{t}_{\mathrm{g}}-\frac{\mathrm{t}_{\mathrm{wi}}+\mathrm{t}_{\mathrm{wo}}}{2}-\mathrm{t}_{\mathrm{p}}} \\
& \mathrm{L}_{\mathrm{h}}=\frac{\mathrm{q}_{\mathrm{a}} \mathrm{R}_{\mathrm{ga}}+\left(\mathrm{q}_{\mathrm{lh}}-\mathrm{W}_{\mathrm{h}}\right)\left(\mathrm{R}_{\mathrm{b}}+\mathrm{PLF}_{\mathrm{m}} \mathrm{R}_{\mathrm{gm}}+\mathrm{R}_{\mathrm{gd}} \mathrm{F}_{\mathrm{sc}}\right)}{\mathrm{t}_{\mathrm{g}}-\frac{\mathrm{t}_{\mathrm{wi}}+\mathrm{t}_{\mathrm{wo}}}{2}-\mathrm{t}_{\mathrm{p}}}
\end{aligned}
$$




\subsubsection{Photovoltaic Calculations}

The calculations of the PV panel facility load necessary according to the annual energy analyses determined by HAP is carried out via Photovoltaic Geographical Information System (PVGIS) performance tool [8] provided by The European Commission's Science and Knowledge Service and installed facility power is calculated with the same method. Typical Meteorological Year (TMY) data is downloaded over PVGIS in "epw" file format and used in HAP analyses. The constant values serving as the basis for the calculations in all scenarios are optimized by the program and presented in Table 2.

Table 2. Constant values for PV panel calculation.

\begin{tabular}{cllll}
\hline Latitude/Longitude & System loss & Slope angle & Azimuth angle & PV technology \\
\hline $40.194^{\circ} / 29.050^{\circ}$ & $14 \%$ & $31^{\circ}$ & $-6^{\circ}$ & Crystalline silicon \\
\hline
\end{tabular}

\subsubsection{Life Cycle Cost Analysis}

For cost analyses of all scenarios, calculations are performed with P1-P2 method [9] regarding an economic life of 20 years. In this method, the difference between the decrease in costs for fuel via alternative system installation and the increase in costs arising from the additional investment necessary for the alternative system is called as Life Cycle Savings (LCS) and formulated as shown in Eqs. 2a, 2b, 2c.

$$
\begin{aligned}
& \mathrm{LCS}=\mathrm{P} 1 \mathrm{CF} 1 \mathrm{FL}-\mathrm{P} 2 \mathrm{Cs} \\
& \mathrm{P} 1=(1-C t e) \mathrm{PWF}(\text { ne }, \mathrm{iF}, \mathrm{d}) \\
& \mathrm{P} 2=\mathrm{P} 2,1+\mathrm{P} 2,2-\mathrm{P} 2,3+\mathrm{P} 2,4+\mathrm{P} 2,5-\mathrm{P} 2,6-\mathrm{P} 2,7
\end{aligned}
$$

In all price offerings and calculations, the unit prices, exchange values, interest and inflation rates of April 2018 were taken into account. The economical parameters used in LCCA calculations are presented in Table 3.

Table 3. Rates and values of economic parameters for LCCA.

\begin{tabular}{lll}
\hline Parameter & Unit & Value \\
\hline Natural gas unit price & TL/kWh & 0.1103 \\
Electricity unit price & TL/kWh & 0.4612 \\
Inflation rate [10] & $\%$ & 10.23 \\
Discount rate [11] & $\%$ & $7.25-9.25$ \\
Economic lifespan & Year & 20 \\
\hline
\end{tabular}

\subsection{Scenario Designs}

All the calculations carried out over three separate scenarios for the case building, namely the current conventional heating-cooling system, and the proposed CCHP and ZEB alternatives. By cross-comparing the obtained results, the 
most economically optimal system is determined. In addition to this, to optimize the ZEB design, three sub scenarios are constructed and cross-compared to determine the optimal system.

\subsubsection{Scenario 1 - The Current System}

The cooling installation consists of 2 air-sourced chiller units with $450 \mathrm{~kW}$ capacity each, and the heating installation consists of 4 gas-fired boilers with $115 \mathrm{~kW}$ capacity each. The electricity demand of the building is fully met by the grid. This scenario is taken as the reference scenario for cost analysis and shown in Figure 2.

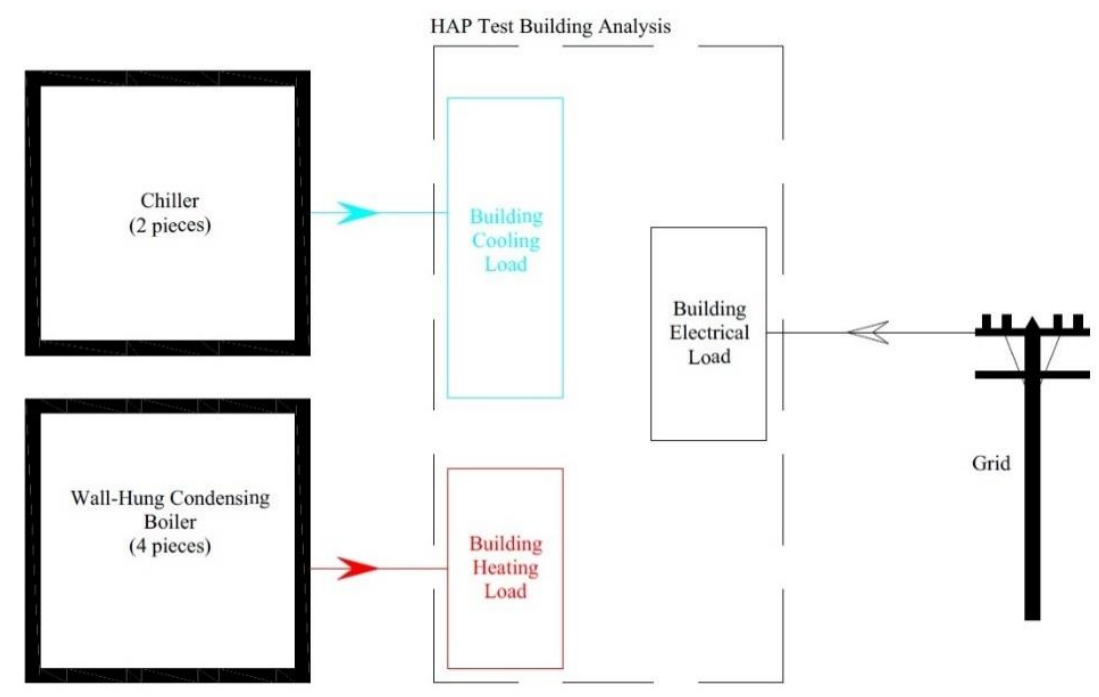

Figure 2. Schematic representation of the scenario 1.

\subsubsection{Scenario 2 - CCHP Plant}

All the energy demand of the case building is met by CCHP plant and natural gas is used as fuel. The CCHP plant is sized in parallel with the values of HAP energy analysis. Because the on-grid-connection option is not possible for electric generated by CCHP plant due to the pertinent legal regulations, the CCHP plant unable to be operated full-time year-long. The calculations are performed in accordance with the human habitation by projecting the CCHP plant to operate 2376 hours annually. During work hours the plant is operated at $100 \%$ capacity and the excess energy generated (electric, heating and cooling thermal energy) is shared with adjacent public buildings in exchange for official billing unit price of the energy provided. The CCHP plant is chosen with the absorption chiller with an EER value of 0.75 and schematically displayed in Figure 3. 


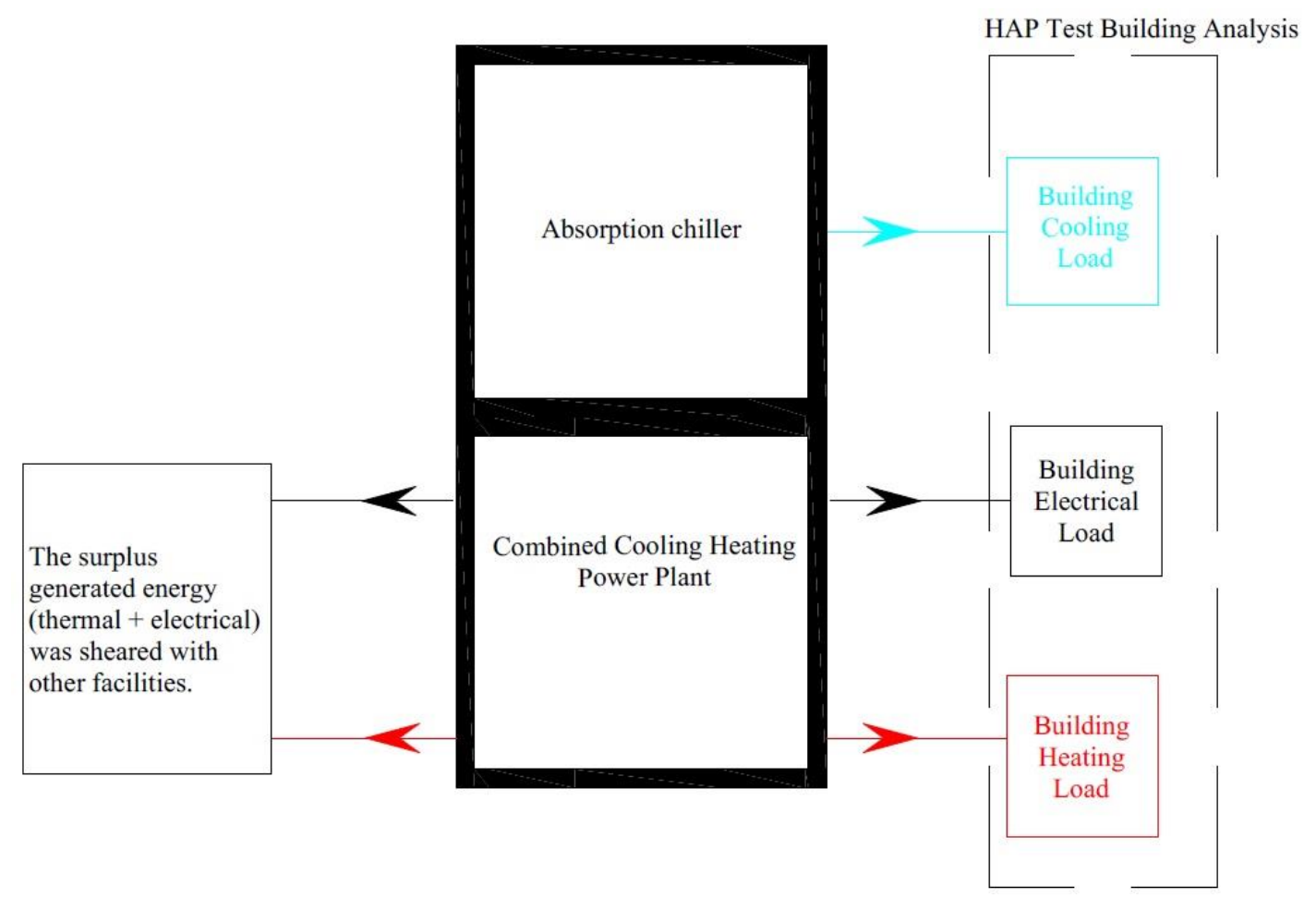

Figure 3. Schematic representation of the scenario 2.

\subsubsection{Scenario 3 - Zero Energy Building, ZEB}

In this scenario GSHP powered by PV panels is used for the heating-cooling operations. The determination of the total capacity of GSHP according to the building load calculations and subsequent selection of suitable equipment is done by the values obtained via the execution of the HAP program and chosen from in compliance with the manufacturing companies' catalogs in order to perform economic analysis. The case building's electrical demand is met completely by using PV panels and the electric generated is connected through a two-way electric meter to the interconnected electrical grid. In this way, surplus electricity can be given to the city grid, eliminating storage and battery costs. In case of insufficient electric generation, the missing demand is drawn from the grid. At the end of each month the balance of both supplying electricity to or withdrawing electricity from the grid is received or given as payment by the billing process according to the regulations. At the end of the year, the sum of the bill values and the revenue values become equal and the building generates as much electricity that has been consumed without using fossil fuel.

\section{$\underline{\text { Sub scenario } 1}$}

For heating process, brine inlet and outlet temperatures of the ground coupled heat exchanger (GCHE) are determined as $1{ }^{\circ} \mathrm{C}$ and $4{ }^{\circ} \mathrm{C}$ respectively based on the study values that as for vertical borehole calculation analyses and GSHP's cooling capacity is chosen to match the building cooling load. The high borehole lengths due to the disparity between building's cooling load and heating load, the former is greater by $70 \%$ than the latter, make extra borehole usage during the heating possible. The fact that higher borehole length can be used for heating process enables GCHE side brine inletoutlet temperatures to be kept higher and the surplus heating capacity emerged to be put in use more efficiently, by virtue of utilizing it to increase Coefficient of Performance (COP) in heating mode. And the fact that the higher these 
temperatures, the higher COP value of GSHP during the heating season from 3.4 up to a level of 3.9 and decreases heat pump's electrical consumption considerably. In this way, brine inlet-outlet temperatures are redetermined as $7-10{ }^{\circ} \mathrm{C}$, economic analyses of the GSHP are performed and compared. For this scenario, 3 GSHP units with identical capacity are used. The facility is shown schematically in Figure 4.

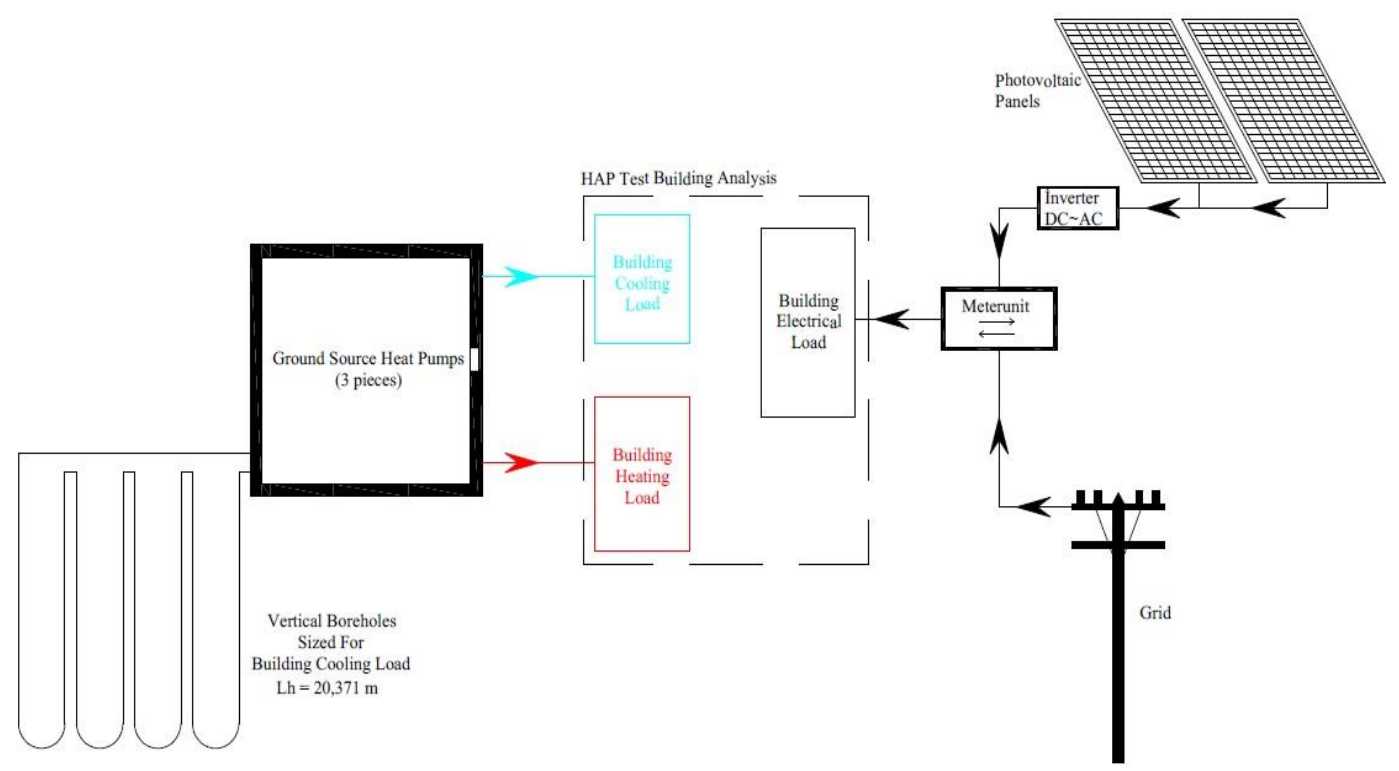

Figure 4. Schematic representation of the scenario 3/1.

\section{$\underline{\text { Sub scenario } 2}$ (GSHP + chiller + air-cooled condenser)}

In order to keep the borehole length to a minimum due to steep borehole costs, the borehole length necessary for a heating process with GCHE side brine inlet-outlet temperatures $1-4{ }^{\circ} \mathrm{C}$ is taken as basis and heat pumps are chosen according to the building heating load. The gap between the total cooling load of the building and the total cooling power of the heat pumps which are originally chosen according to the heating load is bridged by air source chiller units. On the other hand, due to the regime differences between GCHE side brine circulation temperatures of heating and cooling mode, the heat power that should be discharged when GSHP is working in cooling mode exceeds the heat power that can be injected into the boreholes, so the difference is offset by addition of an air-cooled condenser. Thus, in cases when the system designed according to the heat load has a difference with its building cooling load, the atmospheric air is used as a heat sink. For this scenario a system consisting of 2 GSHP's, 1 chiller, 1 air cooled condenser are used and the facility is shown schematically in Figure-5. 


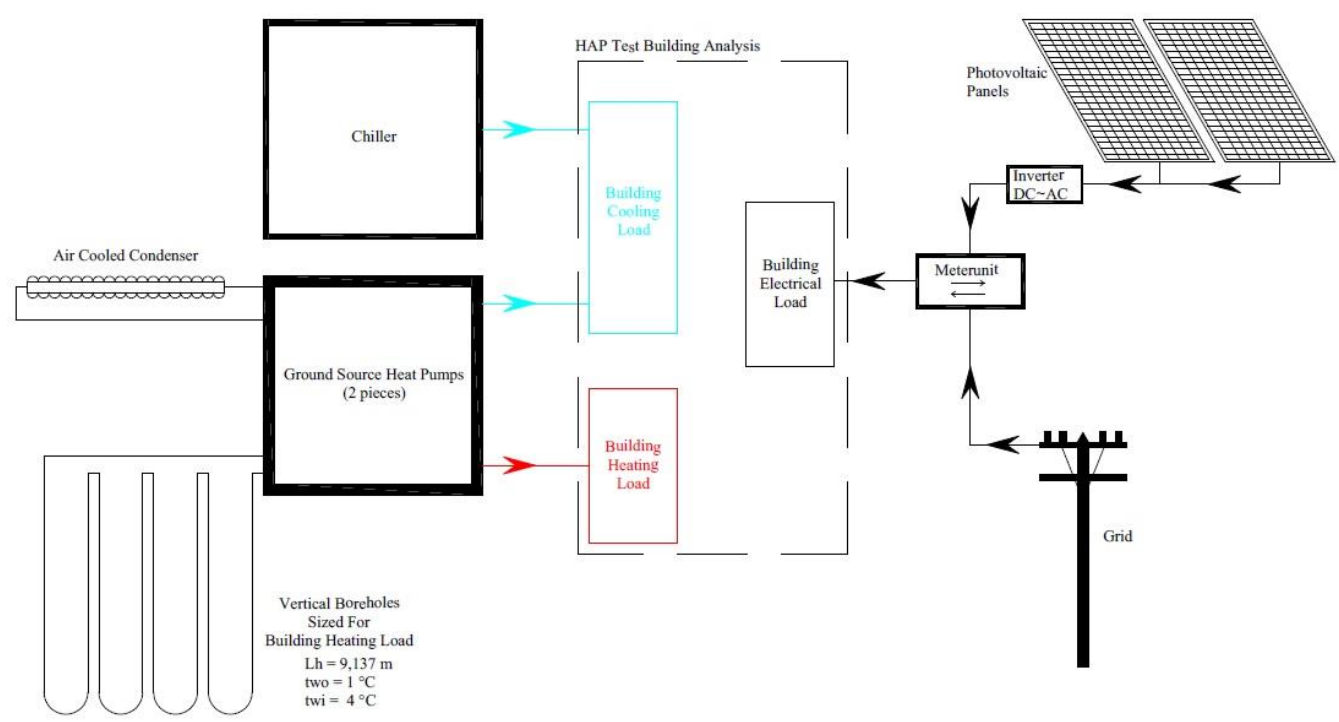

Figure 5. Schematic representation of the scenario $3 / 2$.

\section{$\underline{\text { Sub scenario } 3}$ (GSHP + chiller)}

By taking the borehole length necessary for a heating mode with $7-10{ }^{\circ} \mathrm{C}$ of GCHE brine inlet-outlet temperature as basis, the whole system is sized proportionally to the building heating load and likewise the selection of heat pump is also made according to the building heating load. The excess heat to be discharged to the ground through the borehole by heat pumps in cooling mode, whose heating capacity is selected according to the building heating load, is met by the capacity of the selected borehole length for this scenario, which in turn makes air-cooled condenser usage redundant. The gap between the total cooling load of the building and the cooling capacity of the heat pumps are bridged by a chiller. The borehole length calculated in this scenario is less than the one in sub scenario 1 which is calculated according to cooling load, while it is more than the one in sub scenario 2 which is calculated according to heating load. For the scenario design, 2 GSHP units and 1 chiller is used. The facility is shown schematically in Figure 6.

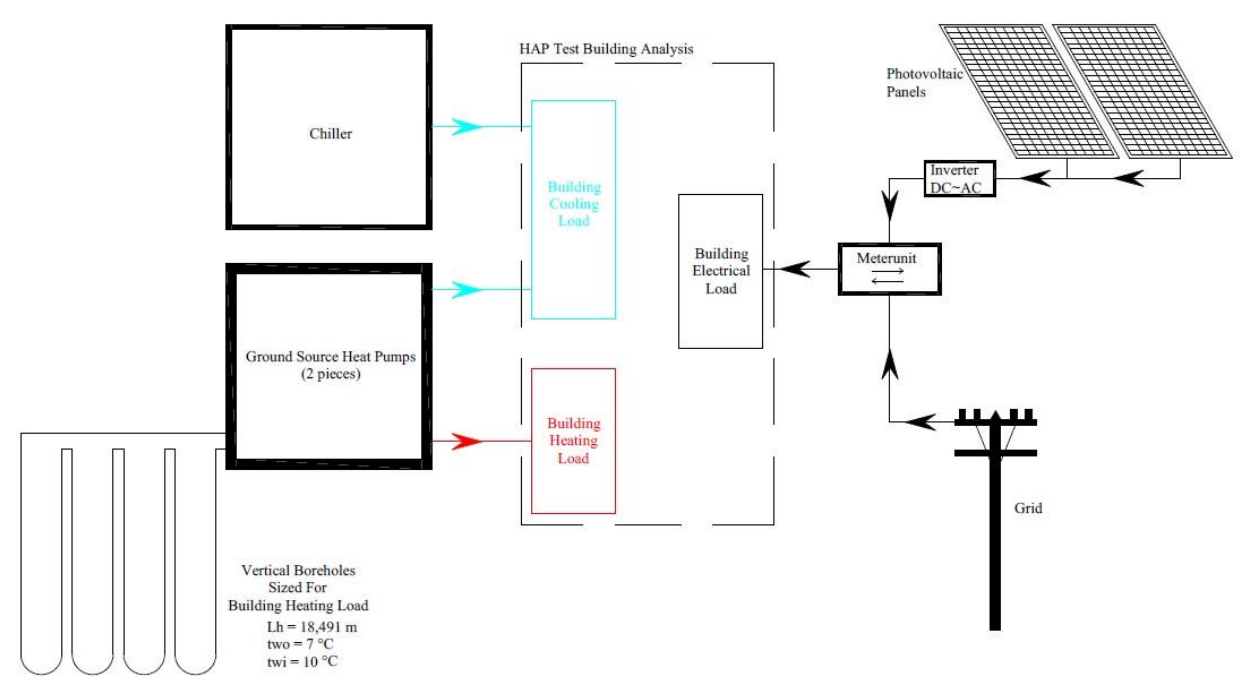

Figure 6. Schematic representation of the scenario $3 / 3$. 


\section{Results and Discussions}

\subsection{Vertical Borehole Calculation}

Operating regimes projected by vertical borehole calculation results and the values eventually derived along with dependent variables are shown at Table 4.

Table 4. Vertical borehole parameters and calculation results.

\begin{tabular}{lll}
\hline Parameter & Unit & Value \\
\hline Borehole length for cooling $\left(\mathrm{L}_{\mathrm{c}}\right)$ & $\mathrm{m}$ & 20,371 \\
Borehole length for heating $\left(\mathrm{L}_{\mathrm{h}}\right)$ & $\mathrm{m}$ & 9,137 \\
Total amount of borehole & Piece & 225 \\
Unit borehole length & $\mathrm{m}$ & 90.54 \\
Borehole layout matrix & - & $15 \times 15$ grid $(\mathrm{W}=84 \mathrm{~m}, \mathrm{~L}=84 \mathrm{~m})$ \\
Ground side brine outlet/inlet temperature & ${ }^{\circ} \mathrm{C}$ & Heating $1 / 4$, Cooling 35/30 \\
User side water outlet/inlet temperature & ${ }^{\circ} \mathrm{C}$ & Heating 50/45, Cooling $7 / 12$ \\
Unit heat extracted from the ground & $\mathrm{W} / \mathrm{m}$ & 34 \\
Unit heat injected into the ground & $\mathrm{W} / \mathrm{m}$ & -44.3 \\
\hline
\end{tabular}

\subsection{CCHP Sizing}

The data from the gas engine and generator set configuration which was initially chosen within the size dictated by HAP energy analysis and load values, along with annual energy generation values are shown at Table 5.

Table 5. Performance and annual energy production values of CCHP plant.

\begin{tabular}{lll}
\hline Parameter & Unit & Value \\
\hline Electric power at the generator terminal & $\mathrm{kW}$ & 800 \\
Fuel consumption & $\mathrm{kW}$ & 1,840 \\
Exhaust heat $\left(120^{\circ} \mathrm{C}\right)$ & $\mathrm{kW}$ & 400 \\
Exhaust outlet temperature & ${ }^{\circ} \mathrm{C}$ & 423 \\
Jacket water heat power & $\mathrm{kW}$ & 420 \\
İntercooler heat power & $\mathrm{kW}$ & 47 \\
Electrical efficiency & $\%$ & 43.48 \\
Thermal efficiency & $\%$ & 47.12 \\
Annual thermal energy generation & $\mathrm{kWh}$ & $2,059,992$ \\
Annual electrical energy generation & $\mathrm{kWh}$ & $1,900,800$ \\
Surplus thermal energy & $\mathrm{kWh}$ & $1,015,714$ \\
Surplus electrical energy & $\mathrm{kWh}$ & $1,392,445$ \\
\hline
\end{tabular}




\subsection{Photovoltaic Power and Energy Analysis}

The monthly total of irradiation incident on PV panels per unit area regarding their regional coordinate data and angle of placement are shown in Figure 7. The total amount of yearly irradiation is calculated as $1697 \mathrm{kWh} / \mathrm{m}^{2}$. The power output of plants according to these irradiation values are determined respectively for each scenario.

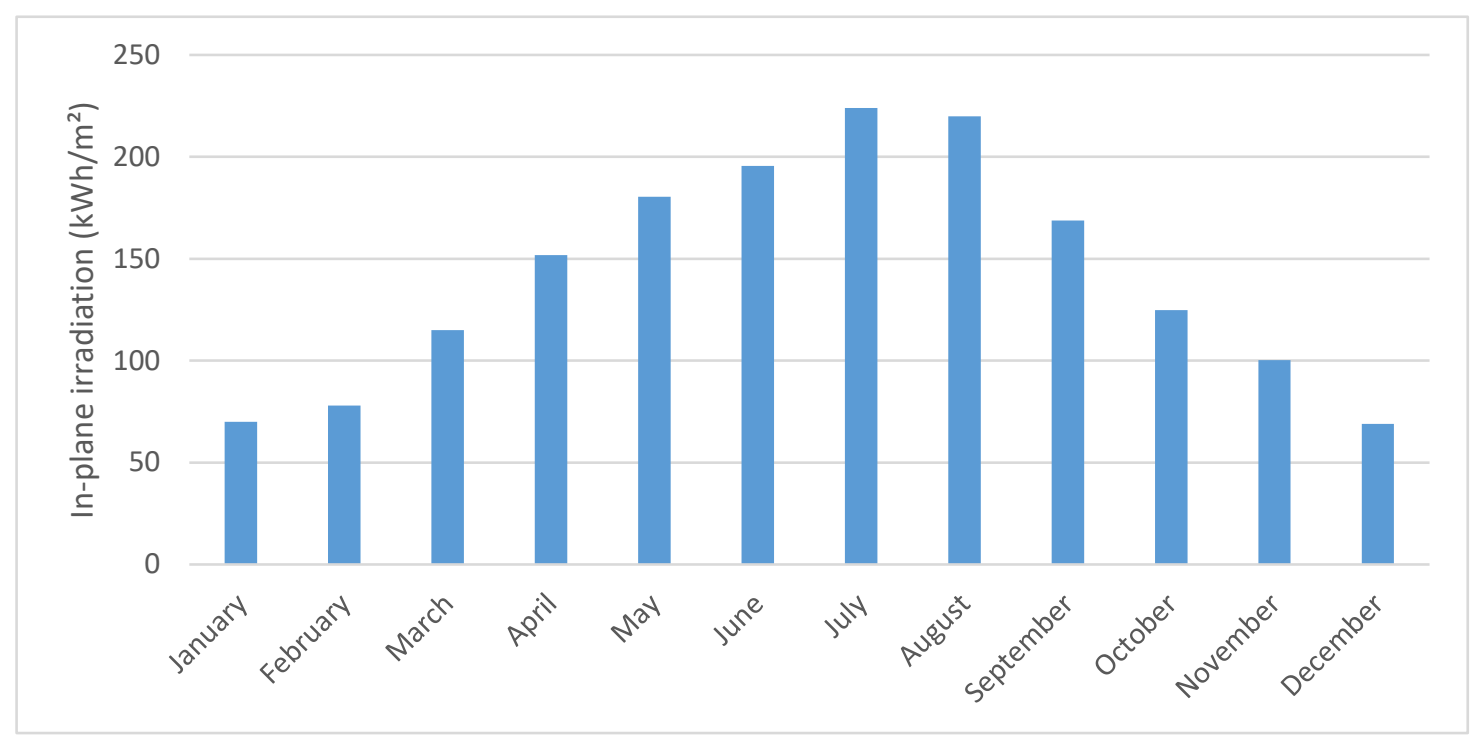

Figure 7. Monthly in-plane irradiation values.

\subsubsection{PV Plant Power and Energy Generation Values for Scenario 3/1-1}

The annual total of energy generation for the PV plant is calculated as $576,142 \mathrm{kWh}$ and its monthly distribution is shown in Figure 8. Total power of the plant is determined as $439 \mathrm{kWp}$.

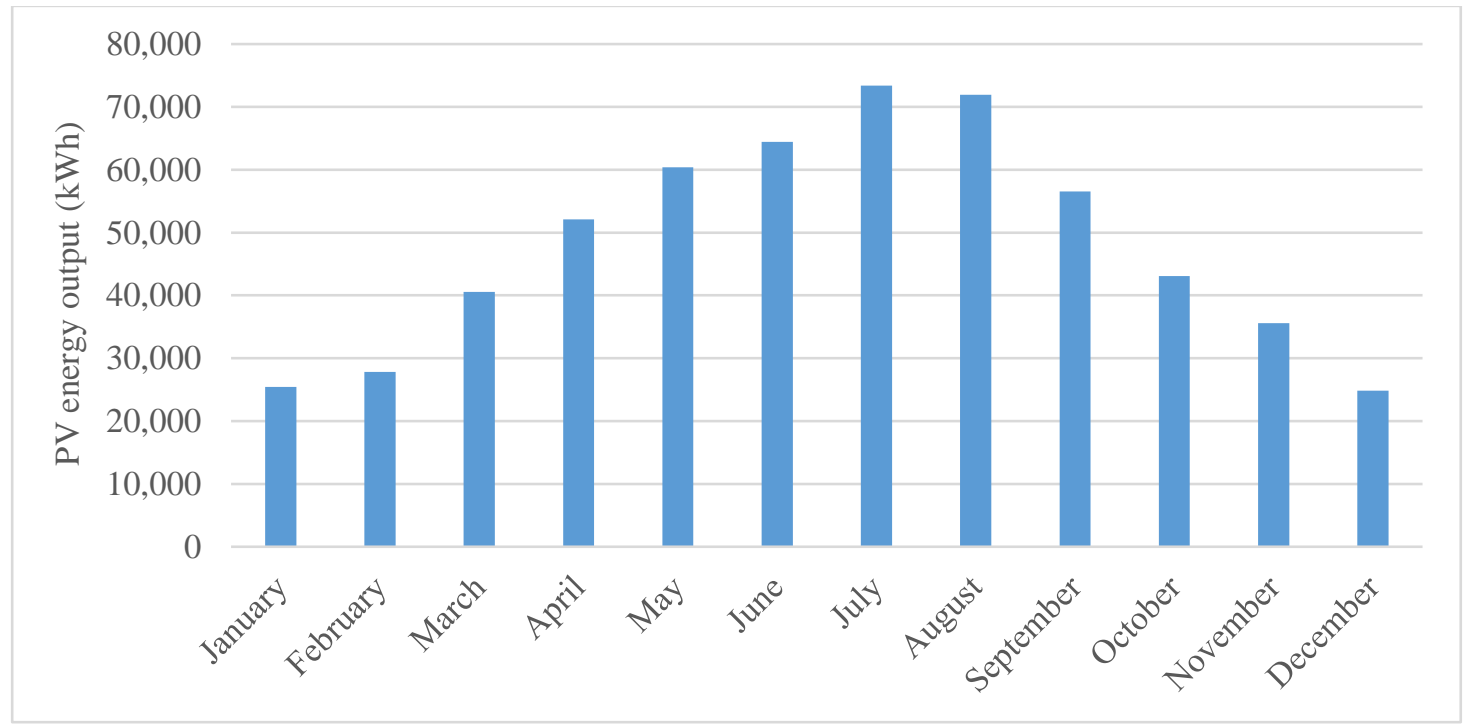

Figure 8. PV plant monthly energy production for scenario 3/1-1. 


\subsubsection{PV Plant Power and Energy Generation Values for Scenario 3/1-2}

The annual total of energy generation for the PV plant is calculated as 560,393 $\mathrm{kWh}$ and its monthly distribution is shown in Figure 9. Total power of the plant is determined as $427 \mathrm{kWp}$.

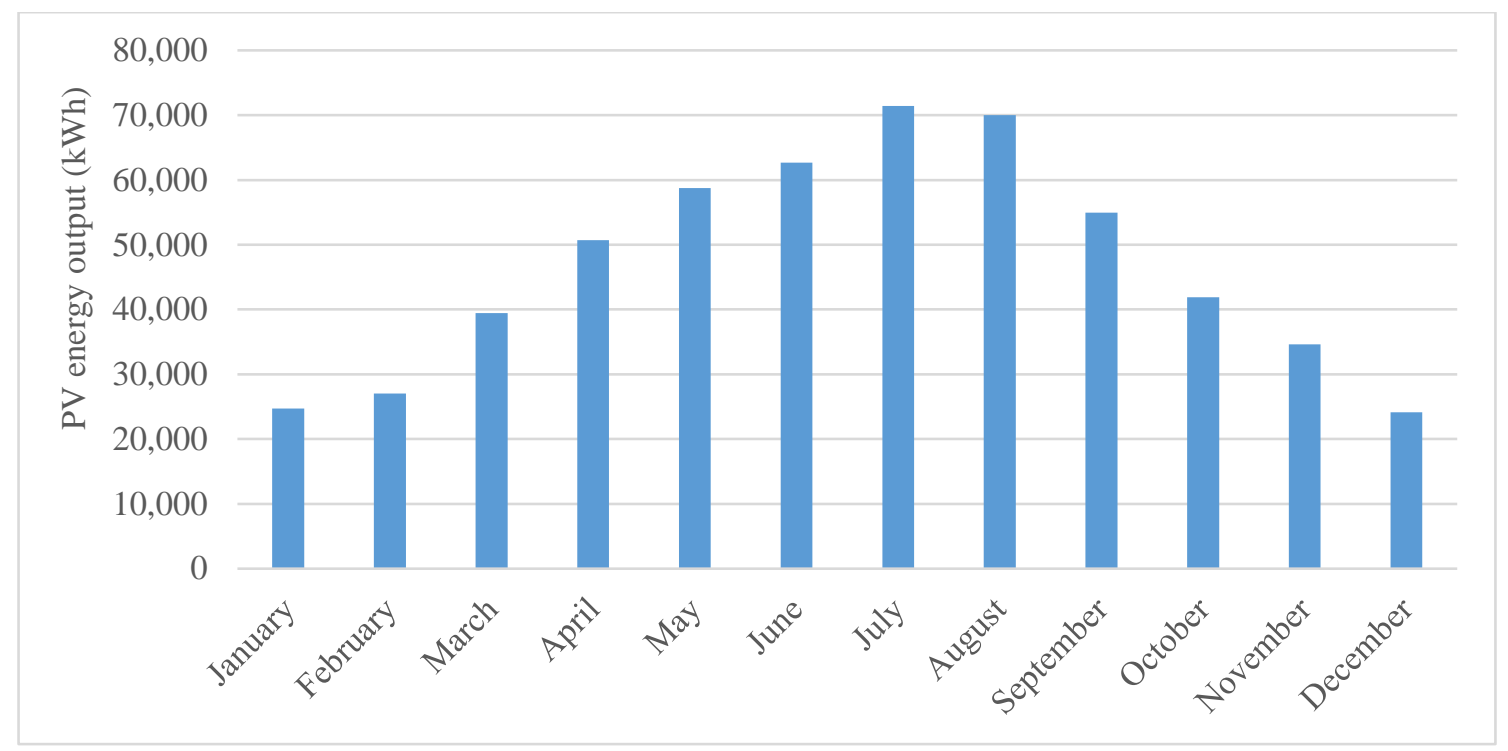

Figure 9. PV plant monthly energy production for scenario 3/1-2.

\subsubsection{PV Plant Power and Energy Generation Values for Scenario 3/2}

The annual total of energy generation for the PV plant is calculated as $607,639 \mathrm{kWh}$ and its monthly distribution is shown in Figure 10. Total power of the plant is determined as $463 \mathrm{kWp}$.

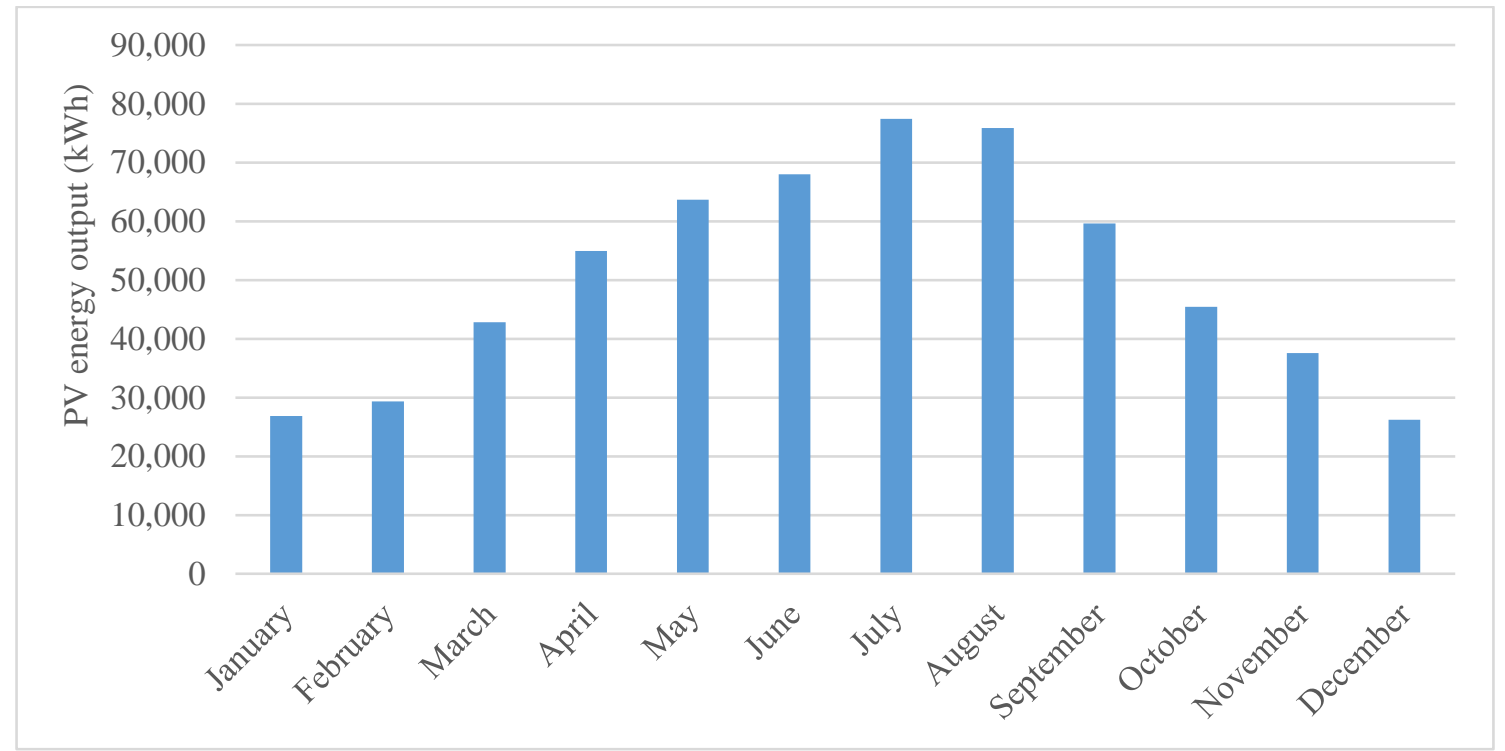

Figure 10. PV plant monthly energy production for scenario $3 / 2$. 


\subsubsection{PV Plant Power and Energy Generation Values for Scenario $3 / 3$}

The annual total of energy generation for the PV plant is calculated as $595,827 \mathrm{kWh}$ and its monthly distribution is shown in Figure 11. Total power of the plant is determined as $454 \mathrm{kWp}$.

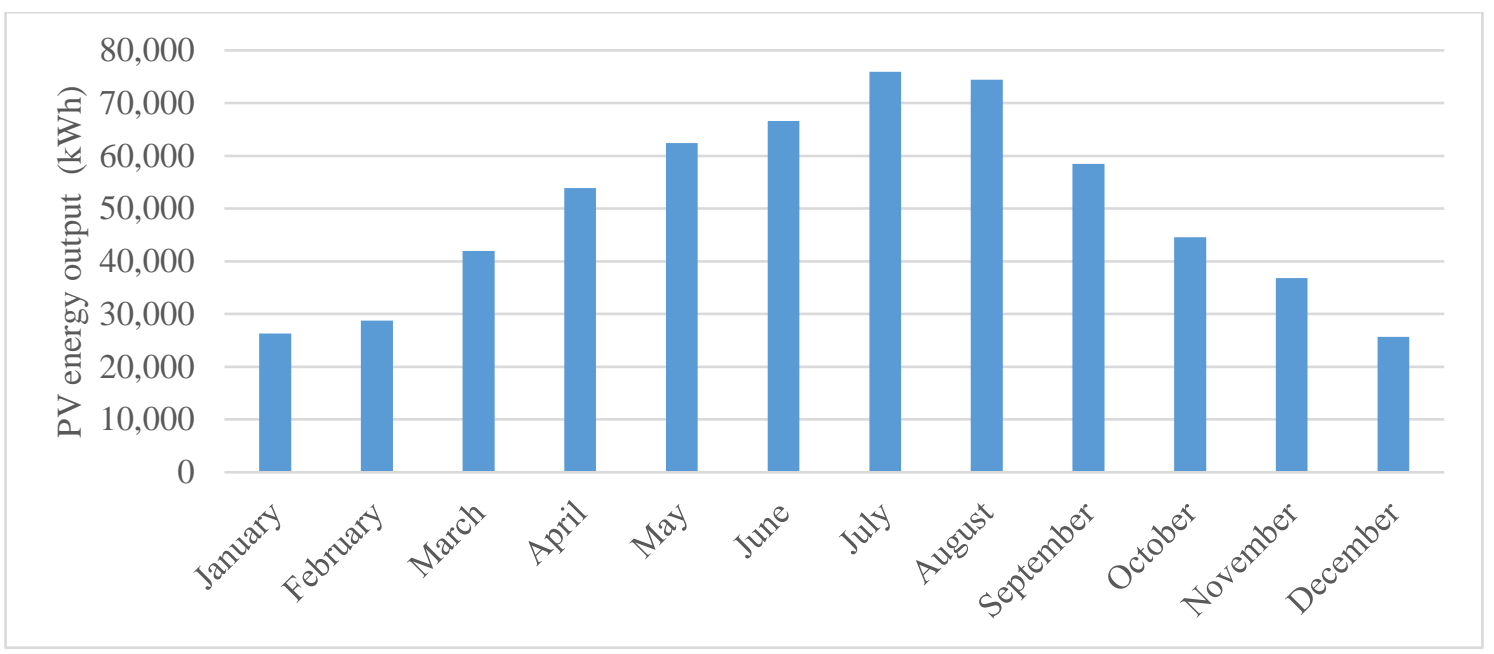

Figure 11. PV plant monthly energy production for scenario $3 / 3$.

\subsection{HAP Analysis}

Design loads of case building are calculated using hourly climate data, the daily record of peak load for cooling being 13:00 hour at a July day with $742.7 \mathrm{~kW}$. All the design values attained are shown in Table 6.

Table 6. Case building cooling and heating loads.

\begin{tabular}{lll}
\hline Space name & Heating $\left(\dot{\mathrm{Q}}_{\mathrm{h}}\right)(\mathrm{kW})$ & $\begin{array}{l}\text { Cooling } \\
(\mathrm{kW})\end{array}$ \\
\hline Kindergarten & 5.9 & 16.5 \\
Mezzanine corridors & 74.7 & 95.9 \\
Cafeteria & 1.1 & 11.1 \\
Warehouse - archive & 33.5 & 16.5 \\
Ground floor corridors & 33.4 & 45.4 \\
Wet areas & 6.3 & 11.5 \\
Masjid - ablution room & 4.4 & 9.1 \\
Guesthouse & 18.8 & 25 \\
Kitchen and dining hall & 40.9 & 105.1 \\
Offices & 120.7 & 317.9 \\
Fitness center & 5.6 & 12.2 \\
Meeting rooms & 45.3 & 76.5 \\
Domestic hot water & 49.2 & - \\
TOTAL & $\mathbf{4 3 9 . 8}$ & $\mathbf{7 4 2 . 7}$ \\
\hline
\end{tabular}


Yearly energy analysis and their dependent variables are also calculated separately for each scenario and presented along with borehole lengths in Table 7.

Table 7. Case building annual energy analysis.

\begin{tabular}{|c|c|c|c|c|c|c|}
\hline & \multirow{4}{*}{$\begin{array}{c}\text { Scenario1 } \\
\text { The } \\
\text { Current } \\
\text { System }\end{array}$} & \multirow{4}{*}{$\begin{array}{c}\text { Scenario2 } \\
\text { CCHP }\end{array}$} & \multicolumn{4}{|c|}{ Scenario3 (ZEB) } \\
\hline & & & \multicolumn{2}{|c|}{ Scenario $3 / 1$} & \multirow{3}{*}{$\begin{array}{c}\text { Scenario } \\
3 / 2\end{array}$} & \multirow{3}{*}{$\begin{array}{c}\text { Scenario } \\
3 / 3\end{array}$} \\
\hline & & & $\mathrm{t}_{\mathrm{wo}}=1^{\circ} \mathrm{C}$ & $\mathrm{t}_{\mathrm{wo}}=7^{\circ} \mathrm{C}$ & & \\
\hline & & & $\mathrm{t}_{\mathrm{wi}}=4^{\circ} \mathrm{C}$ & $\mathrm{t}_{\mathrm{wi}}=10^{\circ} \mathrm{C}$ & & \\
\hline HVAC electricity consumption (kWh) & 272,368 & - & 211,138 & 195,039 & 239,984 & 231,187 \\
\hline Non-HVAC electricity consumption (kWh) & 364,505 & - & 364,505 & 364,505 & 364,505 & 364,505 \\
\hline Total electricity consumption (kWh) & 636,873 & - & 575,643 & 559,544 & 604,489 & 595,692 \\
\hline Natural Gas consumption (kWh) & 373,536 & $4,371,840$ & - & - & - & - \\
\hline Total borehole length (m) & - & - & 20,371 & 20,371 & 9,137 & 18,491 \\
\hline Heating coil load (kWh) & \multicolumn{6}{|c|}{253,783} \\
\hline Cooling coil load (kWh) & \multicolumn{6}{|c|}{389,880} \\
\hline Domestic water load (kWh) & \multicolumn{6}{|c|}{76,480} \\
\hline
\end{tabular}

\subsection{Economic Analysis}

The yearly billing costs of energy consumption is calculated, and along with it yearly operating and maintenance costs and initial plant installation costs are presented in detail for all scenarios in Table 8.

Table 8. Plant initial investment and operating costs.

\begin{tabular}{|c|c|c|c|c|c|c|}
\hline & & Scenario2 & \multicolumn{4}{|c|}{ Scenario3 (ZEB) } \\
\hline & The & CCHP & \multicolumn{2}{|c|}{ Scenario $3 / 1$} & \multirow{3}{*}{$\begin{array}{c}\text { Scenario } \\
3 / 2\end{array}$} & \multirow{3}{*}{$\begin{array}{c}\text { Scenario } \\
3 / 3\end{array}$} \\
\hline & Current & & $\mathrm{t}_{\mathrm{wo}}=1^{\circ} \mathrm{C}$ & $\mathrm{t}_{\mathrm{wo}}=7^{\circ} \mathrm{C}$ & & \\
\hline & System & & $\mathrm{t}_{\mathrm{wi}}=4^{\circ} \mathrm{C}$ & $\mathrm{t}_{\mathrm{wi}}=10^{\circ} \mathrm{C}$ & & \\
\hline & \multicolumn{6}{|c|}{ INITIAL INVESTMENT COSTS (TL) } \\
\hline HVAC equipment & 860,700 & $2,504,700$ & 538,200 & 538,200 & 615,480 & 651,300 \\
\hline Drilling/piping/filling & - & - & $2,712,280$ & $2,712,280$ & $1,216,519$ & $2,461,969$ \\
\hline PV plant establish & - & - & $1,461,822$ & $1,429,655$ & $1,526,160$ & $1,502,033$ \\
\hline \multirow[t]{2}{*}{ Total } & 860,700 & $2,504,700$ & $4,712,302$ & $4,680,135$ & $3,358,159$ & $4,615,302$ \\
\hline & \multicolumn{6}{|c|}{ OPERATING INCOMES (-) /EXPENSES (+) (TL/YEAR) } \\
\hline Maintenance expenses & 6,000 & 81,972 & 19,000 & 19,000 & 19,000 & 19,000 \\
\hline Electricity/oil cost & 293,726 & 58,698 & - & - & - & - \\
\hline Natural gas cost & 41,192 & 482,107 & - & - & - & - \\
\hline Surplus energy saving & & $-763,025$ & - & - & - & - \\
\hline Total & 340,918 & $-140,248$ & 19,000 & 19,000 & 19,000 & 19,000 \\
\hline
\end{tabular}




\subsection{Comparative Cost Analysis}

After determining consumption and investment cost for all scenarios, comparative cost analyses are made. Comparative analyses are made for each alternative system under two main titles, namely the payback period for the extra investment $\operatorname{cost}(\Delta \mathrm{LCS})$ and the payback period for the full investment cost (LCS), with the results presented in the Figure 12.

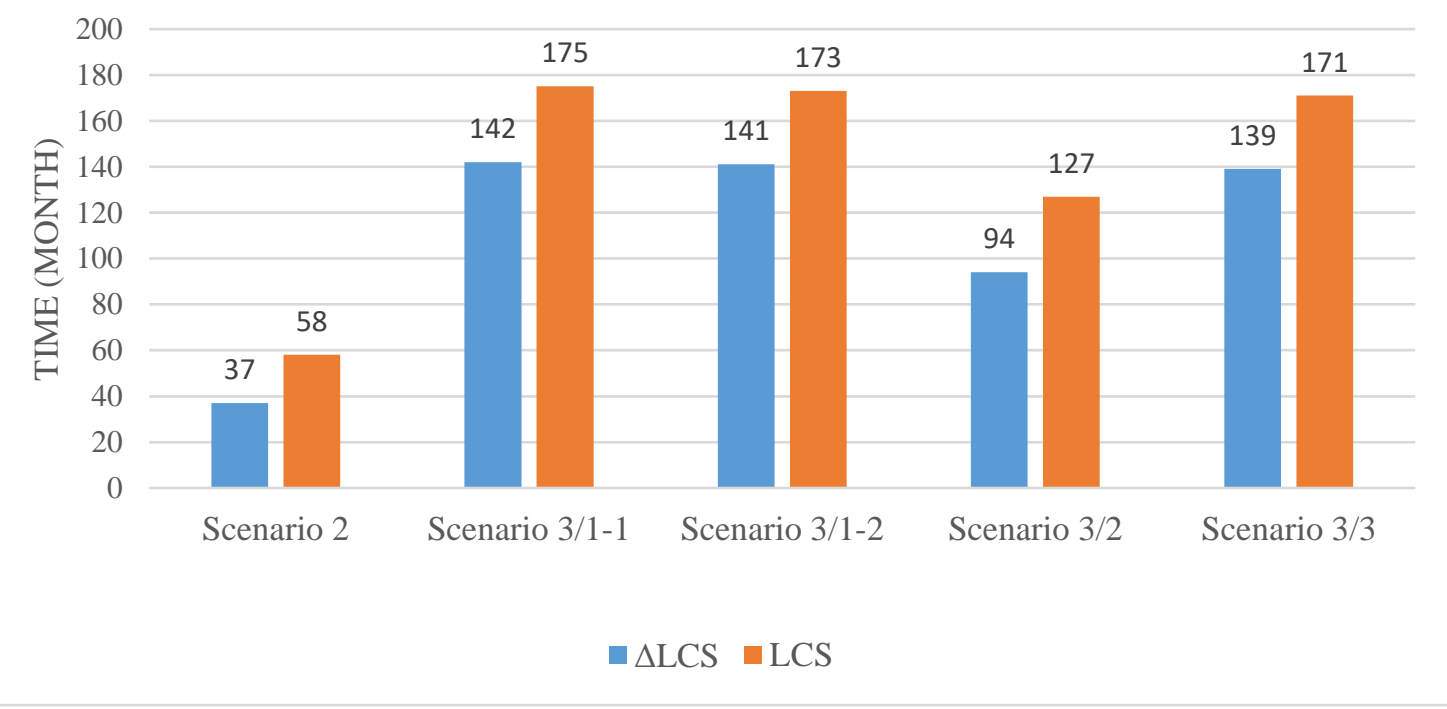

Figure 12. Payback period of plant cost.

For each scenario, the trends for extra investment payback periods since the beginning of investment and operation are presented in Figure 13, 14, 15, 16 and 17. The horizontal zero line (X-axis) in graphics represents the reference system cost which shows the period for the alternative system to redeem its own investment cost.

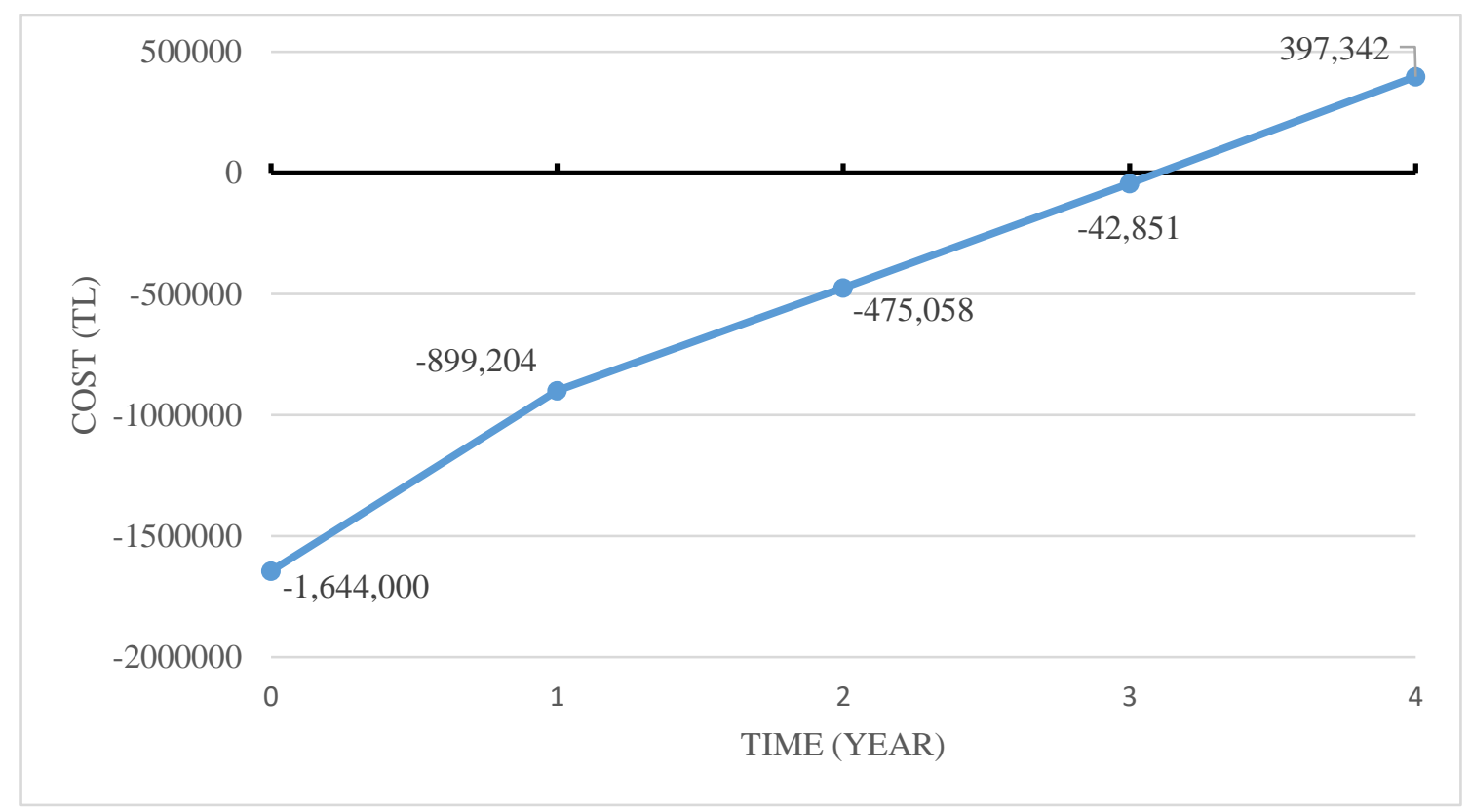

Figure 13. Payback period of extra investment for scenario 2. 


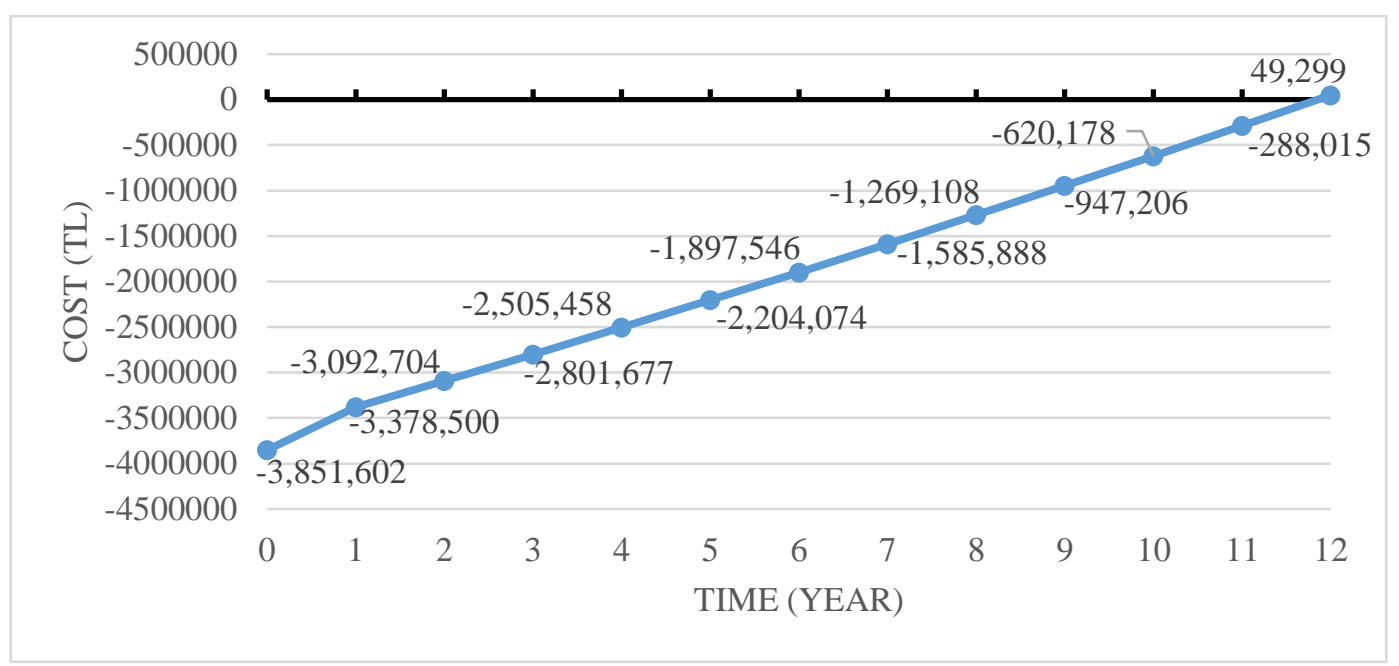

Figure 14. Payback period of extra investment for scenario 3/1-1.

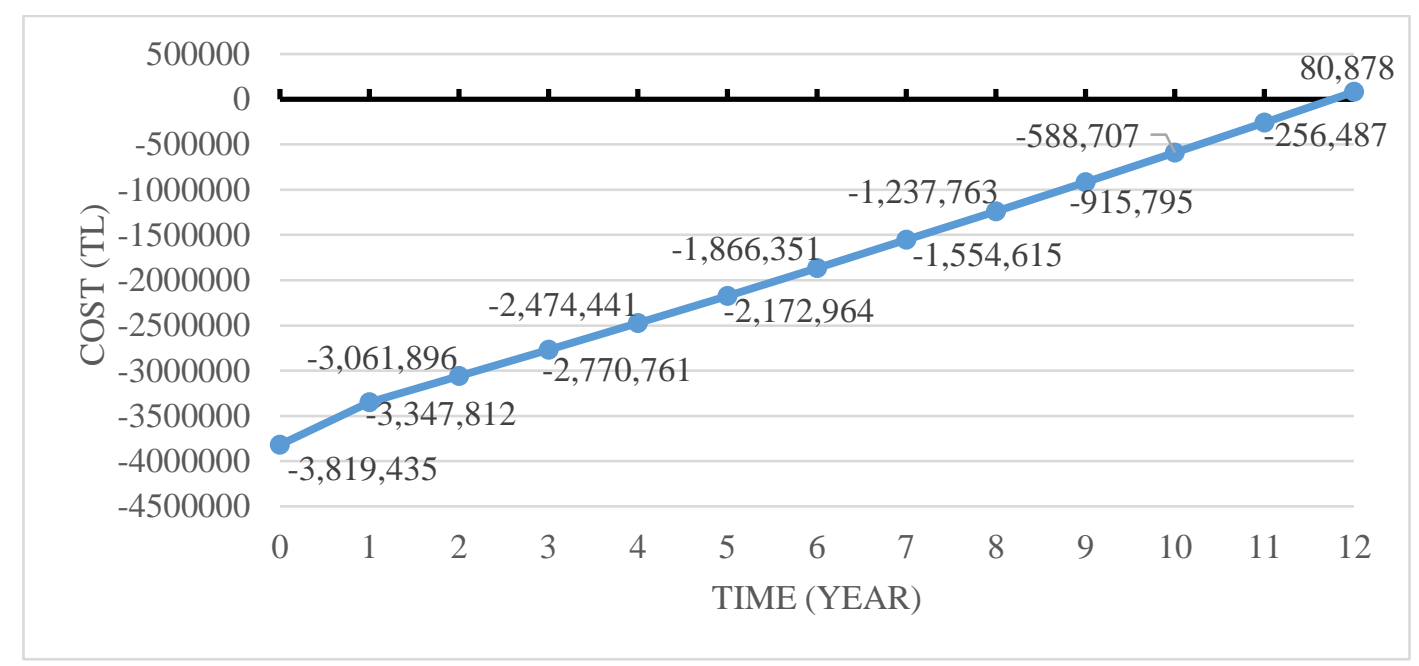

Figure 15. Payback period of extra investment for scenario 3/1-2.

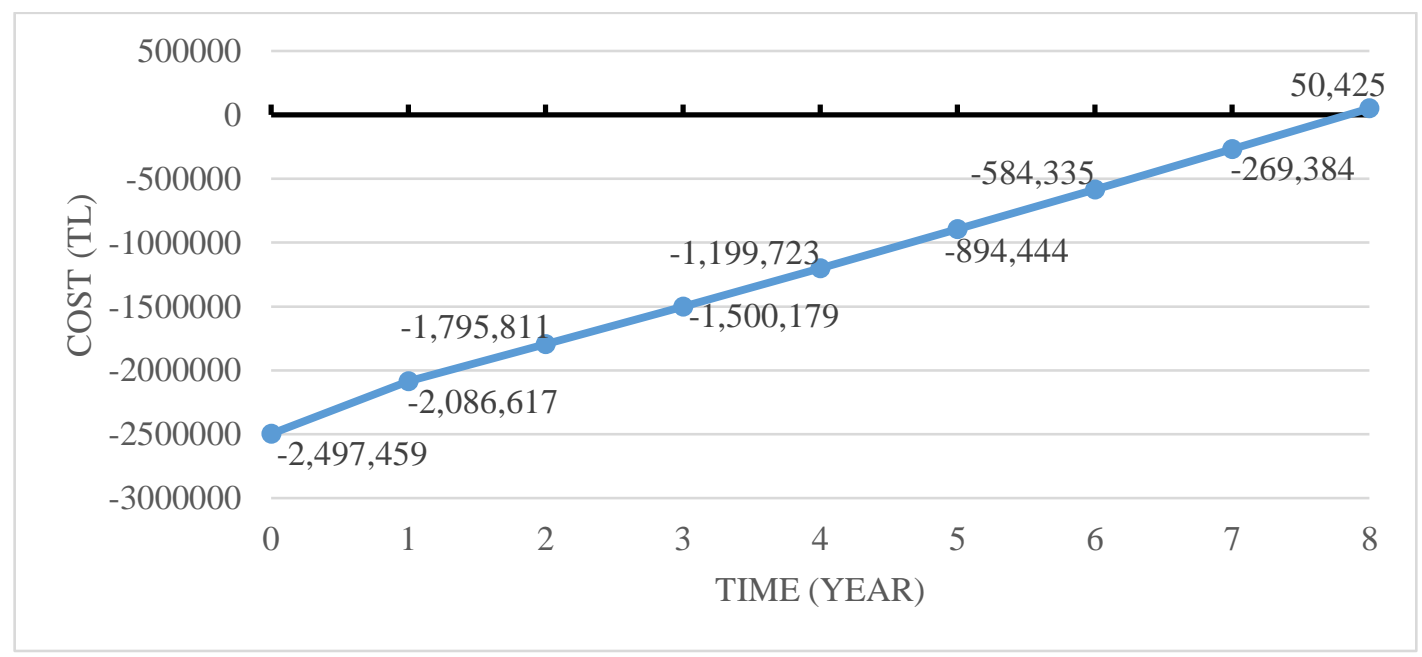

Figure 16. Payback period of extra investment for scenario 3/2. 


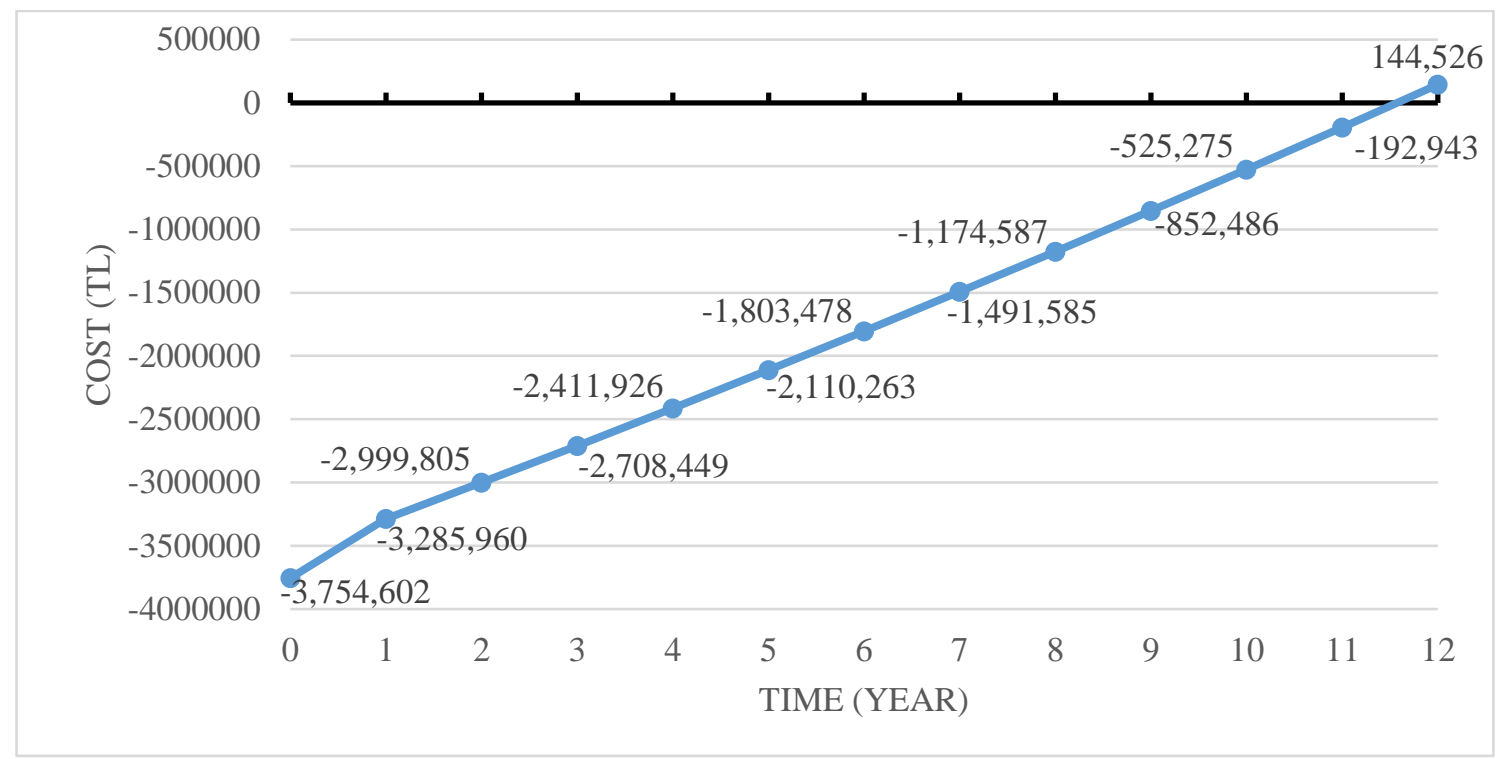

Figure 17. Payback period of extra investment for scenario $3 / 3$.

\subsection{Discussions}

As it is explained in the 2nd scenario above, the CCHP plant to be economically advantageous, 2 prerequisites should be met according to our research. The first is the continuous 100\% capacity operation of the plant during the working hours and non-stop energy generation. The second is the existence of energy demand points which ensure instantaneously generated energy (electrical and thermal) to be consumed instantaneously. As it can be concluded from the calculations, the CCHP system that is operated meeting these two prerequisites with a payback period of 3 years and 1 months, is the shortest scenario.

Similar to this approach Majid Soltani et. al. [12] configured the CCHP system for a cold storage and with the assumption of a system able to sell the generated electricity to the grid and taking the interest rate into account, determined the payback period for the entire investment cost as 4.075 years. Yingjun Ruan et. al. [13] developed a scenario in which the energy generated by the CCHP plant utilized only to meet the demand without putting the surplus to use and performed a subsequent cost analysis. The system was operated per electric load, per thermal load and per maximum operating load, in a total of 3 different models for 4 different buildings (hotel, hospital, depot, office). The CCHP system evaluated in the light of these studies, when operated in maximum capacity, has a payback period of 2-3 years for buildings like hotels and hospitals which inherently have many energy demand points in number and variety, whereas the payback period for office buildings prolongs up to 14 years. The reason for this is that a supply and demand equilibrium is present for buildings like hotels and hospitals between thermal energy (heating, cooling) and electrical energy, which cannot be maintained when office buildings are the case. In fact, when the operating regime is determined according to electrical and thermal load instead of maximum available operating load, the payback period for hotels and hospitals remains around 3 years, on the other hand it stretches to 4.5-5 years for office buildings. 
In conclusion, when the CCHP system in this study operated under the conditions mentioned in the scenario, it conforms to the results obtained by Majid Soltani et. al. [12] who examined a similar scenario. In cases where the system is operated under a regime outside the scenario, due to the fact that it is an office building, as it was indicated in Yingjun et. al. [13] study, the system will lose its economic advantage in terms of system payback period.

The borehole costs, an essential and expensive cost items in ZEB design, become the determining main criterion in LCCA calculations. Determining proper borehole type and length according to peak load is the first and foremost step. U-tubed vertical borehole form with ground-source heat exchanger is used and determined so in HAP analysis. When a GSHP operating regime of $1-4{ }^{\circ} \mathrm{C}$ for heating and $30-35{ }^{\circ} \mathrm{C}$ for cooling is taken as reference for ground side brine, the unit heat absorbed from the earth is determined as $34 \mathrm{~W} / \mathrm{m}$, whereas the unit heat discharged into the earth is determined as $44.3 \mathrm{~W} / \mathrm{m}$. Yu Mingzhi et. al. [14], in a study similar to results of current study, for an arrangement that has $100 \mathrm{~m}$ depth, $5 \mathrm{~m}$ grid array and same inlet-outlet temperatures, reported $30 \mathrm{~W} / \mathrm{m}$ heat absorption and $45 \mathrm{~W} / \mathrm{m}$ heat discharge results, which approximately corresponds to results of current study.

Mitchell Leckner et. al. [15], who performed a ZEB design by excluding GSHP and including PV in a predominantly heating environment like Montreal, Canada, reported 8-11 years payback periods for different scenarios. Even though PV plants appears to be more economically advantageous in terms of investment cost and payback period against their heat pump counterparts, only evaluating energy payback performances excluding initial investment costs yields a 10fold less energy payback time for heat pumps against PV panels, reported by Björn Berggren et. al. [16]. In the study, the net energy ratio is defined as the proportion of annual fluctuations between the two indexes in comparison and can be identified as the energy payback of the investment. According to this claim, in case of the alternative systems being installed on site instead of conventional systems, the average net energy ratios to be acquired annually is declared for PV plant alternative as heating 2.6 - electricity 8.3 - natural gas 4 - oil 4.5 and for heat pump alternative as heating 27.6 - heating by electricity 92.8 - natural gas 66.3 - oil 68.8. These results render heat pump usage unparalleled from the point of energy economy.

When the heat pumps are sorted according to their sources, according to their common operating practices, the one with the highest economic cost in terms of initial investment is the GSHP. In these facilities, vertical borehole design, although driving the cost to the peak, is still preferred over horizontal borehole GSHPs and air-source heat pumps for reasons that it can deal with high heating-cooling loads and it cannot be affected by surface temperature changes. Indeed, in the case study of CIESOL building of the University of Almeria under the climate conditions of Spain [17], by sticking to the ZEB approach, current HVAC system and all the other electrical consumptions are completely fulfilled by PV panels and its energy regeneration value and payback periods are compared with the other three alternative designs. In this study, one of those alternatives is GSHP with a horizontal loop heat exchanger system which satisfies all the heatingcooling needs with this heat pump. In conclusion, 2 different scenarios are carried out and in each one, 20\% more payback period is reported for GSHP with horizontal loop heat exchanger system included design, when compared to the PV panel fed present HVAC system. Therefore, choosing the vertical borehole initially from the point of energy efficiency and implementing hybrid source utilization to mitigate the emerging economic disadvantage is an effective alternative. 
In this study, the addition to air-type condenser to vertical-borehole GSHP make minimization of borehole cost possible by performing borehole length calculation according to the heating load instead of cooling load and in turn dropped the payback period of facility's extra investment cost to a level of 7 years 10 months, as presented in Figure 12. Similarly, Amanda Pertzborn [18] reported that in St. Louis area that has a $13.9^{\circ} \mathrm{C}$ earth temperature, a GSHP plant with a peak cooling load of $659 \mathrm{~kW}$, upon receiving a cooling tower addition, sees a decrease in necessary borehole length from $18,440 \mathrm{~m}$ to $7,073 \mathrm{~m}$. This translates into a drop in plant cost during its life-cycle from 964,769 USD to 657,661 USD.

\section{Conclusions}

According to LCCA calculations, the CCHP plant option, with the condition of using all the energy (electrical and thermal) generated, is the most economically advantageous system with an extra investment cost payback period of 3 years and 1 month. However, in the absence of different consumption spots for the generated energy to be sold and when consumption of the total generated energy is not always viable, this period prolongs considerably. Due to this reason, instead of office buildings, buildings with a load balance between electric and thermal energy consumptions and all day uninterrupted operating regime, the utilization of CCHP systems becomes more advantageous economically.

The payback period of extra investment cost for ZEB based plant is determined as 11 years 10 months for scenario 3/11, 11 years 9 months for scenario 3/1-2, and 11 years 7 months for scenario 3/3. These results call for an optimization proper to the building's consumption of resources along with the borehole length. The selection of borehole length according to the lowest heating and cooling load instead of the highest one and bridging the gap between with air cooled condenser + air-sourced cooler shortens the payback period to 7 years 10 months. In consequence, hybrid ZEB design (vertical borehole GSHP assisted with air cooled condenser + air-source chiller + PV power plant) is suggested as the optimal system for office buildings.

\section{Symbols and Units}

C Flag indicating whether the system is commercial or non-commercial ( 0 or 1$)$

$\mathrm{C}_{\mathrm{F} 1} \quad$ First year unit energy cost delivered from fuel

$\mathrm{C}_{\mathrm{s}}$ Initial system cost

d Market discount rate

$\mathrm{E}_{\mathrm{c}}$ Annual cooling energy ( $\mathrm{kWh}$ )

$\mathrm{E}_{\text {elk }} \quad$ Annual electrical energy $(\mathrm{kWh})$

$\mathrm{E}_{\mathrm{h}}$ Annual heating energy $(\mathrm{kWh})$

FLEnergy saved because of the use of solar energy for first year

i Inflation rate

$\mathrm{i}_{\mathrm{F}}$ Fuel inflation rate

$\mathrm{L}_{\mathrm{c}}$ Borehole length necessary for cooling $(\mathrm{m})$

$\mathrm{L}_{\mathrm{h}}$ Borehole length necessary for heating $(\mathrm{m})$

$\mathrm{n}_{\mathrm{e}}$ Period of economic analysis

P1 Ratio of life cycle fuel cost saving to first year fuel saving 
P2 Ratio of life cycle expenditure incurred from the additional investment to the initial investment

$\mathrm{P}_{2,1} \quad$ Down payment

$\mathrm{P}_{2,2} \quad$ Life cycle cost of the mortgage principal and interest

$\mathrm{P}_{2,3} \quad$ Income tax deductions of the interest

$\mathrm{P}_{2,4} \quad$ Maintenance, insurance and parasitic energy costs

$\mathrm{P}_{2,5} \quad$ Net property tax costs

$\mathrm{P}_{2,6} \quad$ Straight line depreciation tax deduction

$\mathrm{P}_{2,7} \quad$ Present worth of resale value

$\mathrm{PLF}_{\mathrm{m}}$ Monthly part load factor

PWF Present worth factor

$\mathrm{q}_{\mathrm{a}}$ Net annual average heat transfer to the ground (W)

$\mathrm{q}_{\mathrm{l}}, \dot{\mathrm{Q}}_{\mathrm{c}}$ Building design cooling block load (W)

$\mathrm{q}_{\mathrm{lh}}, \dot{\mathrm{Q}}_{\mathrm{h}}$ Building design heating block load (W)

$\mathrm{R}_{\mathrm{b}}$ Thermal resistance of bore $(\mathrm{mK} / \mathrm{W})$

$\mathrm{R}_{\mathrm{ga}}$ Effective thermal resistance of the ground-annual pulse (mK/W)

$\mathrm{R}_{\mathrm{gd}}$ Effective thermal resistance of ground-daily pulse (mK/W)

$\mathrm{R}_{\mathrm{gm}}$ Effective thermal resistance of ground-monthly pulse (mK/W)

$t_{e}$ Effective income tax rate

$\mathrm{t}_{\mathrm{g}}$ Undisturbed ground temperature $(\mathrm{K})$

$t_{p}$ Long-term ground temperature penalty caused by ground heat transfer imbalances $(K)$

$\mathrm{t}_{\mathrm{wi}}$ Heat pump entering liquid temperature for ground side $(\mathrm{K})$

$\mathrm{t}_{\mathrm{wo}}$ Heat pump leaving liquid temperature for ground side $(\mathrm{K})$

U Thermal transmission coefficient $\left(\mathrm{W} / \mathrm{m}^{2} \mathrm{~K}\right)$

$\mathrm{W}_{\mathrm{c}}$ Heat pump electric power for cooling (W)

$\mathrm{W}_{\mathrm{h}}$ Heat pump electric power for heating $(\mathrm{W})$

\section{References}

[1] Xiaodong C., Xilei D., Junjie L. (2016). Building energy-consumption status worldwide and the state-of-theart technologies for zero-energy buildings during the past decade. Energy and Buildings, 128: 198-213.

[2] Shilei L., Yuwei L., Hongwei X. (2018). Study on the configuration and operation optimization of CCHP coupling multiple energy system. Energy Conversion and Management, 177: 773-791.

[3] Islam S.M. (2018). A techno-economic feasibility analysis of hybrid renewable energy supply options for a grid-connected large office building in southeastern part of France. Sustainable Cities and Society, 38: 492508.

[4] Minjin K., Taehoon H., Changyoon J., Hyuna K., Minhyun L. (2020). Development of building driven-energy payback time for energy transition of building renewable energy systems. Applied Energy, 271: 115-162.

[5] Asdrubali F., Ballarini I., Corrado V., Evangelisti L., Grazieschi G., Guattari C. (2019). Energy and environmental payback times for an NZEB retrofit. Building and Environment, 147: 461-472. 
[6] Brys K., Brys T., Sayegh M.A., Ojrzynska H. (2018). Subsurface shallow depth soil layers thermal potential for ground heat pumps in Poland. Energy \& Buildings, 165: 64-75.

[7] Kavanaugh S., Rafferty K. (2014). Geothermal Heating and Cooling Design of Ground-Source Heat Pump Systems. ASHRAE, Atalanta, RP-1674, 420 p. ISBN 978-1-936504-85-5.

[8] The European Commission's science and knowledge service. Photovoltaic Geographical Information System (PVGIS). https://re.jrc.ec.europa.eu/pvg_tools/en/\#PVP. Access date November 8, 2020.

[9] Kalogirou S.A. (2014). Solar Economic Analysis, Solar Energy Engineering Processes and Systems. Elsevier, Oxford, UK. pp. 701-734. ISBN-13: 978-0-12-397270-5.

[10] Central Bank of Republic of Turkey Press Release on Summary of the Monetary Policy Commite meeting 2018-12 https://www.tcmb.gov.tr/wps/wcm/connect/tr/tcmb+tr/main+menu/duyurular/basin/2018/duy201812. Access date November 8, 2020.

[11] Central Bank of Republic of Turkey Press Release on Interest Rates 2018-10 https://www.tcmb.gov.tr/wps/wcm/connect/tr/tcmb+tr/main+menu/duyurular/basin/2018/duy2018-10.

Access date November 8, 2020.

[12] Soltani M., Chahartaghi M., Hashemian S.M., Shojaei A.F. (2020). Technical and economic evaluations of combined cooling, heating and power (CCHP) system with gas engine in commercial cold storages. Energy Conversion and Management, 214: 112877.

[13] Yingjun R., Qingrong L., Weiguo Z., Firestone R., Weijun G., Toshiyuki W. (2009). Optimal option of distributed generation technologies for various commercial buildings. Applied Energy, 86: 1641-1653.

[14] Mingzhi Y., Zhang K., Xizhong C., Aijuan H., Ping C., Zhaohong F. (2016). Zoning operation of multiple borehole ground heat exchangers to alleviate the ground thermal accumulation caused by unbalanced seasonal loads. Energy and Buildings, 110: 345-352.

[15] Leckner M., Zmeureanu R. (2011). Life cycle cost and energy analysis of a Net Zero Energy House with solar combisystem. Applied Energy, 88: 232-241.

[16] Berggren B., Hall M., Wall M. (2013). LCE analysis of buildings - Taking the step towards Net Zero Energy Buildings. Energy and Buildings, 62: 381-391.

[17] Rosiek S., Batlles F.J. (2013). Renewable energy solutions for building cooling, heating and power systems installed in an institutional building. Renewable and Sustainable Energy Reviews, 26: 147-168.

[18] Pertzborn A. (2013). The Design of Hybrid Cooling Tower Heat Pump Systems, PhD Thesis, University of Wisconsin-Madison, WI, USA. 295 p. 